\title{
АКТИВИЗАЦИЯ РАЗЛОМОВ ЦЕНТРАЛЬНОЙ МОНГОЛИИ В ГОЛОЦЕНЕ ПО РЕЗУЛЬТАТАМ ИЗУЧЕНИЯ ДИСЛОКАЦИЙ МОГОДСКОГО ЗЕМЛЕТРЯСЕНИЯ
}

Смекалин О. П., Чипизубов А. В.

\begin{abstract}
Аннотация
С целью определения сейсмотектонической активности разломов в голоценовое время выполнены тренчинговые исследования могодских дислокаций, возникших при катастрофическом Могодском землетрясении (5.01.1967 г., M=7.5-7.8, I0 = 9-10 баллов) в узле сочленения меридионального Хулжингольского разлома и Тулэтского разлома северо-восточного простирания.

Палеосейсмическая интерпретация разрезов сейсмодеформаций и радиоуглеродное датирование проб позволили определить кинематику и впервые получить абсолютный возраст палеособытий, предшествовавших Могодскому землетрясению. Анализ тектонических условий реализации очагов землетрясений объясняет сложное строение дислокаций в эпицентральной области Могодского землетрясения, в пределах которых выделено три отрезка, различающихся амплитудами и кинематикой подвижек. Результаты исследований свидетельствуют об неоднократной активизации Тулэтского и Хулжингольского разломов в позднем плейстоценеголоцене. Установлен абсолютный возраст наиболее поздней активизации в интервале 596-994 годов н. э. для Тулэтского разлома и в интервале 11379-6235 лет до н. э. для Хулжингольского разлома. По строению деформаций в разрезах канав в зоне Тулэтского разлома определяются как минимум два палеособытия взбросовой кинематики с амплитудой последнего из них 2.8 м. В зоне Хулжингольского разлома палеоземлетрясение имело сдвиговую кинематику. Амплитуды деформаций указывают на то, что в прошлом в разломном узле происходили землетрясения сопоставимые по энергии с событием 1967 года или более сильные. Полученные данные о времени доисторических землетрясений и сопровождавших их амплитудах деформаций позволили оценить скорости движений по разломам. Для Хулжингольского разлома скорость сдвига оценивается в интервале $0.2 \div 0.3$ м/тыс.лет. Для Тулэтского взброса скорость относительного вертикального смещения крыльев составляет $0.5 \div 0.7$ м/тыс.лет.
\end{abstract}

\section{Ключевые слова:}

активный разлом, сейсмичность, палеоземлетрясение, тренчинг, радиоуглеродное датирование 


\title{
АКТИВИЗАЦИЯ РАЗЛОМОВ ЦЕНТРАЛЬНОЙ МОНГОЛИИ В ГОЛОЦЕНЕ ПО РЕЗУЛЬТАТАМ ИЗУЧЕНИЯ ДИСЛОКАЦИЙ МОГОДСКОГО ЗЕМЛЕТРЯСЕНИЯ
}

\author{
О.П. Смекалин, А.В. Чипизубов
}

Институт земной коры СО РАН, 664033, Иркутск, ул. Лермонтова 128.

\section{ВВЕДЕНИЕ}

Могодское землетрясение (5 января 1967 г., $\mathrm{M}_{\mathrm{s}}$ 7.5 [Huang, Chen, 1986]), одно из сильнейших внутриплитных землетрясений, уже на протяжении более чем полувека остается объектом внимания сейсмологов и сейсмогеологов. В публикациях, посвященных этому событию, определены фокальные механизмы основного толчка и афтершоков [Баяр, 1975; Москвина, 1978; Tapponnier, Molnar, 1979; Huang, Chen, 1986], детально описаны остаточные сейсмотектонические деформации и макросейсмические проявления [НацагЮм и др., 1971; Хилько и др., 1985; Bayasgalan, Jackson 1999; Рогожин и др., 2008 и др.], но практически не рассматривался сейсмический режим Могодского очага в голоцене. Чтобы восполнить этот пробел и установить повторяемость сильных сейсмических событий, механизм деформаций, реализуемый в очагах доисторических землетрясений, нами в 2017 году дислокации Могодского землетрясения были изучены в разрезах горных выработок. Основные результаты исследований приводятся в настоящей статье.

Территория восточнее Хангайского поднятия, включая правобережье Орхона, вплоть до 60-х годов XX века относилась к сейсмобезопасным районам в связи со слабой сейсмической активностью. На схеме активных разломов [Апродов, 1960], составленной после экспедиционных работ и изучения материалов дистанционных методов (топокарты, аэрофото), будущая эпицентральная зона Могодского землетрясения расположена вне зон влияния установленных на то время активных разломов. Несмотря на то, что Нацаг-Юмом в 1962-63 годах в междуречье Орхона - Тола были обнаружены следы палеосейсмических дислокаций, некоторые из которых имеют собственные названия среди местных жителей (Гунжийн Зам, Аврага Могойн Мур, Чингисийн Зам [Нацаг-Юм и др., 1971]), Могодское землетрясение всё-таки стало "неожиданным". 
При землетрясении 5 января 1967 года образовалась серия разрывных нарушений по зонам Хулжингольского и Тулэтского разломов. Длина дислокаций по этим разломам составляла 40 и 13 км [Нацаг-Юм и др., 1971]. В настоящее время протяженность дислокаций, фиксируемых по космоснимкам и полевым наблюдениям, сократилась до 18 и 9 км соответственно.

В зоне меридионального Хулжингольского разлома дислокации характеризуются разнообразием форм. На скальных породах это преимущественно линейные или зигзагообразные трещины, часто с пустотами, с вертикальной амплитудой, не превышающей 1.3 м (рис. 1, 2). Приподнятым является восточное крыло. Там, где коренные породы перекрыты рыхлыми осадками вдоль линии разлома эшелонированной цепью вытягиваются валы сжатия сопряженные с рвами растяжения, взаимное расположение которых свидетельствует о правостороннем сдвиге. Амплитуда горизонтального смещения, установленная по отдельным реперам в долинах водотоков, достигает 2.5 м [Нацаг-Юм и др., 1971]. Главные разрывы сопровождались большим числом оперяющих трещин с небольшой амплитудой смещения. Наиболее эффектные деформации возникли в заболоченном днище Хулжингольской впадины напротив Могодсомона. Они представляли собой нагромождения пластов мерзлого грунта высотой до 3 метров. Но именно эти образования бесследно исчезли в течение первых лет после землетрясения.

Дислокации Тулэтского разлома (рис. 3) представляют собой прямолинейный взбросовый уступ северо-западного простирания с приподнятым северо-восточным крылом. Высота уступа от 1 до 5 м.

\section{ГЕОЛОГО-ТЕКТОНИЧЕСКАЯ СИТУАЦИЯ В ЭПИЦЕНТРАЛЬНОЙ ОБЛАСТИ ЗЕМЛЕТРЯСЕНИЯ.}

Вышедший на поверхность очаг Могодского землетрясения расположен в пределах вулканогенно-осадочной толщи Орхонского раннемезозойского прогиба. Эта тектоническая структура связана с особым мезозойским этапом развития территории Монголии [Томуртогоо, 1972] и является наиболее крупной в Орхон-Селенгинской системе прогибов. Орхон-Селенгинская система прогибов с севера ограничена левобережьем долины реки Селенги, занимает всю площадь междуречья Орхона и Толы, и протягивается далее на северо-восток на расстояние около 450 км при ширине от 30 до 120 км. С юга Орхон-Селенгинская система через региональный Баянгольский разлом граничит с каледонским складчатым обрамлением Хангай-Хэнтэйской зоны [Тектоника ..., 1974]. В неотектоническом плане Баянгольский разлом является одной из ветвей 
Монголо-Охотского линеамента и отчетливо трассируется в современном рельефе нанизанными на него межгорными линейными впадинами. Баянгольский разлом также служит южной границей распространения неогеновых базальтов (рис. 4).

Обе тектонические зоны (Орхон-Селенгинская и Хангай-Хэнтэйская) образованы в результате активизации западного фланга Монголо-Охотского пояса на фундаменте из мозаики террейнов активных континентальных окраин, спаянных в кембрийское время в единый Центрально-Монгольский микроконтинент [Tomurtogoo, 2002].

С середины мезозоя, с закрытием структур на западном фланге Монголо-Охотского бассейна [Гордиенко и др., 2019], Орхон-Селенгинская система прогибов испытывает складчато-глыбовые деформации, значительную роль в которых играют движения по вновь возникшим разломам, определившим, в частности, и угловатую форму границ Орхонского прогиба. Разломы имеют преимущественно северо-западное и широтное простирание, что свидетельствует о влиянии на формирование мезозойских структур деструкции каледонского субстрата. Именно такого простирания складки и разрывные нарушения характерны для Восточно-Хангайского выступа в левобережье Орхона в частности и для Хангайского свода в целом.

В неотектоническом плане к структурам северо-западного простирания в пределах Орхонского прогиба относится пограничное горстовое поднятие хребта Тулэт, к осевой части которого приближен разлом, фрагментарно вскрывшийся при Могодском землетрясении. Вероятной причиной наследования новейшими структурами плана деструкции каледонского фундамента является сокращение мощности пермьраннетриасовых отложений у южных границ Орхон-Селенгинского прогиба, в отличие от его центральной зоны, где мощность отложений, перекрывающих каледонское основание, превышает 11 км [Тектоника ..., 1974]. В связи с этим на значительной площади ОрхонСеленгинской зоны отсутствуют неотектонические структуры северо-западного простирания.

Четко обособленная в рельефе новейшая структура Тулэтского горста сформирована благодаря активизации разломов северо-западного простирания, ответвляющихся от зоны Баянгольского разлома. Юго-запад Орхонского прогиба характеризуется максимальными (до 3700 м) изопахитами абзогской свиты ( $\left.\mathrm{T}_{3}\right)$ [Томуртогоо, 1972], что характеризует данную часть Орхонского прогиба как наиболее активную в период его заложения в раннем мезозое. И в период неотектонической активизации оформившееся на этом месте Тулэтское поднятие является наиболее активной морфоструктурой Орхон-Тольского междуречья. 
Меридиональные разломы Северной Монголии характерны для границ односторонних грабенов позднего мезозоя. Некоторые из них расположены вблизи контура Орхонского прогиба. Однако, Хулжингольский разлом, также меридионального простирания и тяготеющий к западной границе Орхонского прогиба, не имеет связи со структурами мезозойской активизации. По нему заложена надразломная внутригорная впадина шириной не более 4 км и длиной около 40 км. Западное ограничение впадины извилисто в плане и полого переходит в склон хребта Номгоны-Нуру. Восточный борт впадины представлен прямолинейными относительно крутыми передовыми фасами хребтов Халзан-Хамар и Сархиагын-Бэл (рис. 5). В работе [Тектоника ..., 1974] высказывается мнение, что сейсмическая активизация меридионально ориентированных впадин связана с влиянием новейших рифтовых ("байкальских") структур Северной Монголии.

B плане Хулжингольский разлом в средней части имеет S-образный изгиб, вызванный смещением осевой линии хребта Халзан-Хамар к востоку относительно осевой линии хребта Сархиагын-Бэл. В связи с этим дислокации Могодского землетрясения в зоне Хулжингольского разлома можно условно поделить на два отрезка: южный и северный. Дислокации южного отрезка прижаты к подножию хребта Сархиагын-Бэл и имеют амплитуды горизонтального смещения 1.2-2.5 м, и вертикального 0.8-1.3 м. На северном отрезке главные дислокации образовались вдоль осевой линии Хулжингольской впадины, но к настоящему времени сохранились лишь слабовыраженные рвы в подножии хребта Халзан-Хамар. Они имеют длину от нескольких метров до 15-20 метров и ширину до полуметра. Непосредственно после землетрясения здесь отмечались прерывистые уступы, обращенные в сторону впадины, с амплитудой вертикального смещения 0.1-0.2 м, редко до 0.35 м. Таким образом, дислокации северного и южного отрезков отличаются как по локации относительно бортов впадины, так и по амплитудам смещения. Это связано, прежде всего, со строением геологических толщ, вмещающих очаг землетрясения.

Северный отрезок дислокаций находится в пределах Халзанского горста северозападного простирания, в современном эрозионном срезе представленного образованиями перми и нижнего триаса (рис. 5). В процессе мезозойской активизации породы Орхонского прогиба, как и всей Северной Монголии испытали значительные складчатые и дизъюнктивные деформации. Амплитуда вертикальных перемещений смежных блоков достигали 2-3 км, максимум 4 км [Тектоника ..., 1974]. Амплитуда поднятия Халзанского горста была не меньшей чем мощность позднетриасовых и юрских отложений [Тесtonic map of Mongolia, 2002], слагающих северное крыло Орхонского прогиба. По данным приведенным в [Томуртогоо, 1972; Моссаковский, Томуртогоо, 1972] эта амплитуда могла 
составить более 1800 м (взяты минимальные значения мощностей абзогской свиты $\left(\mathrm{T}_{3}\right)-$ 800 м и могодской свиты $\left(\mathrm{T}_{3}-\mathrm{J}_{1}\right)-1000$ м для центра Орхонского прогиба). Выступ Халзанского горста обусловлен локальным поднятием в каледонском фундаменте прогиба, что определяет различия в свойствах пород, вмещающих очаг землетрясения не только вблизи поверхности, но и на глубинах, близких к фокальному слою.

\section{ОПРЕДЕЛЕНИЕ АБСОЛЮТНОГО ВОЗРАСТА И АМПЛИТУД}

\section{ПАЛЕОЗЕМЛЕТРЯСЕНИЙ}

При ранее проводимых сейсмогеологических работах [Рогожин, Балжинням, 1995] были детально зафиксированы остаточные деформации поверхности как главные признаки генетического типа дислокаций, их кинематики и энергетических характеристик.

В 2017 году с целью изучения сейсмического режима очага Могодского землетрясения дислокации в зонах Хулжингольского и Тулэтского разломов были вскрыты горными выработками. С помощью экскаватора были пройдены канавы, глубина и протяженность которых позволили получить первые кондиционные данные о параметрах палеоземлетрясений. Канава 1 пройдена через дислокации в зоне Хулжингольского разлома, канава 2 вскрыла взбросовый уступ в зоне Тулэтского надвига (рис. 5). В таблице и схеме корреляции также дана датировка из небольшой, пройденной вручную в 2007 году, канавы 3. Ее схематический разрез приведен в публикации [Рогожин и др., 2008]. В канаве 3 была отобрана проба из почвенного горизонта перекрытого отложениями коллювиального клина.

Канава 1 имеет длину 30 м и вскрывает поперек три параллельных неглубоких (до 0.5 м) рва с пологими бортами. В продольных стенках канавы непосредственно под почвенно-растительным слоем тальвегов рвов вскрыты деформации в виде вертикальных раскрытых трещин шириной от 0.2 до 0.5 м. Этими трещинами разбит слой плотной "окаменевшей" супеси на глубину от 1.0 до 1.5 м (рис. 6). Глубже этого слоя в относительно рыхлой песчано-дресвяно-щебнистой толще следы трещин теряются. Расстояние между трещинами от 2 до 10 м. Отсутствие вертикальной компоненты перемещений по трещинам свидетельствует о преимущественно сдвиговом смещении разбитых на блоки приповерхностных слоев. То, что трещины выходят непосредственно к дневной поверхности, заполнены рыхлым материалом и пространственно связаны с выраженными на поверхности дислокациями Могодского землетрясения, дает нам основание считать, что эти трещины возникли в 1967 году.

В торцевой стенке канавы 1 при ручной зачистке была вскрыта клиновидная наклонная трещина, заполненная несортированным мелким и средним щебнем из 
нижележащих слоев (рис. 7). Эта трещина в отличие от трещин, образованных в 1967 году, перекрыта рыхлыми отложениями, в которых залегают погребенные почвенные горизонты, как деформированные в результате палеособытия при образовании трещины, так и перекрывшие деформацию. Определение возраста палеособытия осуществлено путем датирования проб из погребенных почв: деформированной трещиной (ЛУ-8794) и перекрывающей трещину (ЛУ-8795). Радиоуглеродный возраст проб и их калиброванные значение (календарная дата) приведены в таблице и на схеме корреляции (рис. 8). Временной интервал разрывообразующего палеособытия заключается в пределах 113796235 ВС (лет до н. э). Такие особенности в строении деформации как наличие зияющего пространства между стенками трещины, падение трещины в северо-восточном направлении и поднятие северо-восточного крыла, свидетельствуют о взбросо-сдвиговом механизме реализации очага при палеособытии. Так как, при изучении могодских дислокаций установлены следы нескольких палеоземлетрясений в зонах Хулжингольского и Тулэтского разломов, то для удобства идентификации и избегания путаницы каждому из палеоземлетрясений нами присвоены краткие латинские обозначения. Для палеоземлетрясения, о котором говорилось выше, мы присваиваем индекс KhPEQ (Kh Khuljingol, PEQ - PaleoEarthQuake). Соответственно, для палеоземлетрясений, следы которых вскрыты в канаве, расположенной в зоне Тулэтского надвига, нами присвоены индексы TuPEQ1 и TuPEQ2.

Канава 2 (рис. 9) пройдена через сейсмогенный взбросовый уступ и представляет собой расчистку бортов и углубление в тальвеге эрозионного вреза, ортогонально пересекающего линию Тулэтского разлома. В разрезе канавы (рис. 10) отражена суммарная деформация склоновых отложений в результате нескольких разрывообразующих событий, включая землетрясение 1967 года. В месте проходки канавы амплитуда деформаций 1967 года была незначительной. Отсутствие в подножии уступа коллювия из щебенки слоя (Е) свидетельствует о том, что деформация 1967 года не сопровождалась образованием сколько-либо значимой "свободной поверхности", и вероятнее всего, амплитуда подвижки не превышала мощность современного почвенного покрова (А). О том, что основная по амплитуде деформация, связанная с разрывом слоев (B) и (Е), не имеет отношения к землетрясению 1967 года, свидетельствуют датировки радиоуглеродных проб ЛУ-8806 и ЛУ-8807, отобранных из кровли погребенного почвенного слоя (В) и основания коллювиального клина (С) соответственно.

Наличие коллювиального клина, наряду с плоскостями разрыва, является основным признаком сейсмического происхождения уступа [Paleoseismology, 2009]. Отложения коллювиального клина (С) представлены фрагментами козырьковой части надвинутого 
при палеоземлетрясении (TuPEQ1) северо-восточного крыла разлома, обрушившейся в течение некоторого времени после подвижки. По вещественному составу коллювиальный клин представлен щебенкой из слоев $(\mathrm{E})$ и $(\mathrm{H})$, перемешанной с темно-серым песком и дресвой почвенного горизонта (А), а также отдельными фрагментами почвы с большим содержанием гумуса. Из одного из таких фрагментов, оказавшегося в основании коллювиального клина нами была отобрана и датирована радиоуглеродным методом проба ЛУ-8807 для определения верхнего интервала абсолютного возраста палеособытия (TuPEQ1). Коллювиальный клин перекрыл часть почвенного горизонта (B), примыкающую к плоскости разлома (F1). Между коллювиальным клином и погребенной почвой (В) есть отчетливая граница в виде слоя сортированного среднезернистого темнокоричневого песка мощностью до 5 см (слой (D) на разрезе канавы). Этот песок осаждался из водных потоков незадолго до палеоземлетрясения (TuPEQ1), или, что менее вероятно, сразу после него до обрушения козырька с висячего крыла.

Основная деформация палеособытия (TuPEQ1) в разрезе канавы связана с разрывом и смещением по плоскости (F1) слоев (B) и (Е). Плоскость разлома (F1) проходит между смежными торцевыми окончаниями слоя (Е) в лежачем и висячем крыльях разлома. Границы слоя (Е), примыкающие к плоскости разрыва, отчетливо прослеживаются по контрасту цветов - серого у слоя (Е) и рыже-серого у супесчанощебнистой массы (обозначено индексом $(\mathrm{H})$ на разрезе), которая вероятно под воздействием сжатия выдавлена вверх и "размазана" вдоль плоскостей разрыва. Из кровли погребенной почвы (В) была отобрана проба ЛУ-8806 на радиоуглеродный анализ для определения нижней границы интервального возраста палеособытия (TuPEQ1). Календарный возраст предшествовавшего Могодскому землетрясению палеособытия (TuPEQ1) заключен в интервале 596-994 годов н.э. (см таблицу и схему корреляции на рис. 8).

Признаки более раннего сейсмического события (TuPEQ2) связаны с подвижками по разлому (F2), по которому коренные породы (зеленовато-серые верхнетриасовые трахиандезитовые порфириты) надвинуты на рыхлые щебнистые отложения слоя (G). Непосредственно в зоне контакта коренные породы дезинтегрированы до состояния плотноупакованной дресвы.

Простейшие геометрические построения позволяют определить кинематические параметры сейсмических подвижек (верхняя вставка на рис. 10). По разнице высот залегания пологих участков кровли слоя (Е) в лежачем и висячем крыльях разлома определяется амплитуда суммарной подвижки при двух последних сейсмических событиях: землетрясении 1967 года и предшествовавшем ему палеоземлетрясении 
(TuPEQ1). C учетом крутого падения сместителя (F1) вертикальная компонента смещения, определяемая по кровли разорванного слоя, и истинное смещение по сместителю (при отсутствии горизонтальной компоненты) практически равны между собой и составляют 3.5 м. В суммарной амплитуде (3.5 м) доля смещения при землетрясении 1967 г., определяемая по мощности почвенного покрова на неподверженном разрушению участке висячего крыла, незначительна и составляет не более 0.7 м. О кинематике событий, предшествовавших палеоземлетрясению (TuPEQ1), можно лишь сказать, что при них подвижки шли по сместителю (F2), падающем на северо-восток под углом $43^{\circ}$, а значение их амплитуды превышало сумму мощностей вскрытой части коренных пород (1.5 м) и слоя (G) (0.9 м). Определение разовых амплитуд для событий, предшествовавших палеоземлетрясению (TuPEQ1), из разреза канавы 2 невозможно.

Интервал времени между палеособытием (TuPEQ1) и предшествующим ему палеособытием (TuPEQ2) значительно более продолжителен, чем временной промежуток между землетрясением 1967 г. и палеоземлетрясением (TuPEQ1). Это следует из того, что к моменту события (TuPEQ1) участок горного склона, вскрытый канавой, представлял собой пологий уступ высотой не более 1.1 м (разница между современной высотой уступа и амплитудой поднятия за два последних землетрясения). Об отсутствии перед событием (TuPEQ1) резкого перегиба в рельефе свидетельствует плавное уменьшение мощности слоя (Е) в направлении основания уступа. Значит, предшествовававшее событию (TuPEQ1) сейсмическое затишье было достаточно длительным для того, чтобы был сглажен уступ от более ранних сейсмических подвижек, явные следы которых имеются в разрезе канавы.

Предпоследнему палеособытию (TuPEQ2) зоны Тулэтского разлома вероятно соответствует образование трещины, вскрытой в торцевой стенке канавы 1 в зоне Хулжингольского разлома (палеоземлетрясение KhPEQ).

На основании результатов тренчинговых исследований можно сделать следующие выводы. Дислокации в эпицентральной зоне Могодского землетрясения формировались в течение позднего плейстоцена - голоцена при как минимум трех разрывообразующих событий, включая землетрясение 1967 г. Предшествовавшие событию 1967 года вскрытия разломов на меридиональной и диагональной ветвях происходили в разное время: последнее палеособытие (TuPEQ1) - в VII-X веках н.э. в зоне Тулэтского разлома и предпоследнее, более древнее событие (KhPEQ) - около 8.3-13.4 тыс. лет назад в зоне Хулжингольского разлома.

Приблизительные значения скоростей относительного перемещения крыльев разломов определяются следующими расчетами. Максимальное правостороннее смещение по Хулжингольскому разлому в 1967 г. составило 2.5 м [Нацаг-Юм и др., 1971]. Временной 
интервал между последними двумя событиями составляет от 8202 лет (календарная дата пробы ЛУ-8795 равная cal BC 6235 + 1967) до 13346 лет (календарная дата пробы ЛУ-8794 равная cal BC 11379 + 1967). Отношение амплитуды смещения (2.5 м) к значениям границ интервала времени (8202 - 13346) дает нам интервал приблизительных значений скорости горизонтального смещения $0.2 \div 0.3$ м/тыс.лет.

Для определения значения скорости взброса Тулэтского разлома мы исходим из амплитуды разового смещения, определенного палеосейсмической интерпретацией канавы 2. Амплитуда разового смещения при землетрясении 1967 г. по крутой плоскости разлома в направлении с северо-востока на юго-запад составила 0.7 м. Временной промежуток между двумя последними событиями лежит в интервале 973 - 1371 (расчеты выполнены по схеме, представленной в предыдущем абзаце). Используя эти числовые значения амплитуды и времени получаем приблизительное значение скорости взброса в пределах интервала $0.5 \div 0.7$ м/тыс.лет.

\section{ОБСУЖДЕНИЕ РЕЗУЛЬТАТОВ}

О сейсмотектонической активности, разбитого на блоки Орхон-Селенгинского прогиба свидетельствуют не только молодой расчленённый рельеф, но и сейсмодислокации, широко распространенные здесь. Они были обнаружены Нацаг-Юмом при сейсмогеологическом обследовании территории в 1962-1963 гг. Что же касается непосредственно дислокаций, образовавшихся в 1967 году, то Л. Нацаг-Юм, И. Балжинням и Д. Монхо пишут следующее: "Новообразованные дислокации главным образом связаны с обновлением субмеридионального разлома, имеющего местное название "Гунж Зам" (Дорога Принцессы). Главный разлом Могодского землетрясения является по сути дела обновлённым фрагментом швов палеосейсмических дислокаций, образовавшихся в историческое время при крупных землетрясениях" [Нацаг-Юм и др., 1971]. Авторы цитированного фрагмента, рассматривая Могодские дислокации как единый разлом, не исключают того, что вновь возникшие дислокации не по всей своей протяженности наследуют более древние разрывы, а значит, вдоль линии Могодской дислокации существуют фрагменты с разным временем обновления (как и с разной степенью сохранности) сейсмодеформаций.

Естественно деление разлома 1967 г. на два основных отрезка: меридиональный и диагональный. Повод рассматривать Могодские дислокации не как единый разрыв, а как узел сочленения двух разломов, дают и определения механизма очага землетрясения 5 января 1967 года. Неоднозначность в определении механизма очага и расчетов сейсмического момента связывается сейсмологами со сложными процессами в очаге, 
предопределившими значительную длительность вступления P-волн [Huang, Chen, 1986]. В [Москвина, 1978] говорится, что "... процесс в очаге имел сложный характер многократного вспарывания, осуществившегося в виде серии толчков. ... При таком характере вспарывания механизм очага, определенный по знакам первых вступлений Рволн, может и не отражать всей сложности очагового процесса, будучи справедливым только для его начальной фазы".

Построения, выполненные Jie Huang и Wang-Ping Chen, при тщательном изучении Рволн, позволило им сделать предположение, что главный толчок вероятнее всего является комбинированным, состоящим из трех подсобытий, различающихся энергией и фокальными механизмами [Huang, Chen, 1986]. Эпицентры подсобытий и их фокальные механизмы приведены на рис. 5. Процесс вспарывания шел с севера на юг и для первых двух подсобытий механизм определяется как правостороний сдвиг. Третье подсобытие имеет ярко выраженную взбросовую компоненту. Определенно взбросовый механизм имеет и наиболее сильный из афтершоков (20 января 1967 г., $\mathrm{M}_{\mathrm{s}}=7.0$ ), эпицентр которого приближен к южной, Тулэтской, ветви Могодских дислокаций, а обе нодальные плоскости имеют северо-западное простирание. Эпицентр этого афтершока практически совпадает с эпицентром одного из альтернативных решений для третьего подсобытия главного толчка Могодского землетрясения.

Разделяя главный толчок на три подсобытия, Jie Huang и Wang-Ping Chen, тем не менее, рассматривают дислокации Могодского землетрясения принадлежащими единому разлому, у которого близ южного фланга простирание плавно меняется с субмеридионального на юго-западное, что и отражено на помещенной в их работе блокдиаграмме, в подписи к которой говорится, что "крутопадающий на восток сдвиг имеет небольшой изгиб у своего южного фланга, где происходит еще и взбросообразование" [Huang, Chen, 1986]. Однако, с помощью космических снимков (а также при наземном обследовании) устанавливается, что и Хулжингольская, и Тулэтская ветви дислокаций практически прямолинейны вплоть до их пересечения, и в месте пересечения сходятся под прямым углом. Приподнятый блок вблизи места пересечения разломов разбит множеством трещин как параллельных меридиональной ветви дислокаций, так и расположенных косо по отношению к ней. Максимальным сосредоточением разрывов характеризуется не только разломный узел, но и северное окончание меридиональной ветви, что свидетельствует о концентрации напряжений на концах Хулжингольского разрыва и является еще одним подтверждением его существования и развития как самостоятельной структуры. 
Если с активностью Хулжингольского разлома связано формирование надразломной внутригорной впадины, то Тулэтский разлом - это, прежде всего, результат новейшей активности Тулэтского поднятия. Его неотектоническая активизация отражена в наличии более древних следов подвижек по разломам, параллельных Тулэтской ветви дислокаций, располагающихся как к юго-западу, так и к северо-востоку от нее. Вертикальные смещения по этим разломам придают юго-западному и северо-восточному склонам Тулэтского поднятия ступенчатую форму. Ступени отчетливо трассируются выходами скальных останцев порфиритового состава. Эти разломы превышают протяжённость Тулэтской ветви дислокаций и после пересечения меридиональной Хулжингольской ветви протягиваются на значительное расстояние в северо-западном направлении.

\section{ЗАКЛЮЧЕНИЕ}

Изучение сейсмодислокаций Могодского землетрясения в разрезах горных выработок позволило впервые оценить активность сейсмического очага на протяжении голоцена. Применение тренчинга, дало возможность получить абсолютный возраст доисторических землетрясений, кинематику и амплитуды разовых смещений. Выполненные исследования по определению абсолютного возраста на разных ветвях могодских дислокаций и анализ геолого-тектонического строения эпицентральной области дают основание предполагать о независимой активизации Хулжингольского и Тулэтского разломов в доисторическом прошлом. Более молодым является обновление Тулэтского разлома. Кинематические характеристики палеоземлетрясений свидетельствуют о постоянстве напряженно-деформированных свойств земной коры и тектонических процессов, определяющих формирование современного рельефа рассматриваемой территории. Проведенные исследования показывают, что сейсмотектонические проявления очага Могодского землетрясения зависят от строения вмещающей очаг геологической среды, сформированной поступательным ходом геологической истории.

\section{БЛАГОДАРНОСТИ}

Авторы статьи выражают искреннюю благодарность монгольским коллегам академику Монгольской Академии наук С. Демберелу и А. Баясгалану за помощь в организации и проведении полевых работ.

Исследование выполнено при поддержке РФФИ в рамках научного проекта № 20-0500357 A. 
Баяр Г. Механизм очага афтершоков Могодского землетрясения. Могодын давталт ходлелийн голомтын механизм. "Эрдэм шинжилгээн бутээл", 1975, №13 (монг.).

Голенецкий С.И. Землетрясения в СССР. М.: Наука, 1970.

Гордиенко И.В., Метелкин Д.В., Ветлужских Л.И. Строение Монголо-Охотского складчатого пояса и проблема выделения Амурского микроконтинента // Геология и геофизика, 2019, т. 60 (3), с. 318-341.

Хилько С.Д., Курушин Р.А., Кочетков В.М., Балжинням И., Монхоо Д. Землетрясения и основы сейсмического районирования Монголии. Под ред. Солоненко В.П., Флоренсов Н.А. Москва, Изд-во Наука, 1985, 224 с.

Москвина А.Г. Механизм и параметры очага Могодского землетрясения 5 января 1967 г. и его афтершоков // Физика Земли, 1978, № 1, с. 3-17.

Моссаковский А.А., Томуртогоо О. Схема стратиграфии пермских и раннемезозойских вулканогенно-осадочных образований Орхон-Селенгинского прогиба // Доклады Академии наук СССР, 1972, т. 206 (5), с. 1181-1184.

Нацаг-Юм Л., Балжинням И., Монхо Д. Сейсмическое районирование Улан-Батора. Москва, Изд-во Наука, 1971, с. 54-82.

Рогожин Е.А., Балжинням И. Новые данные о геологических проявлениях Могодского землетрясения 1967 г. (Центральная Монголия) // Доклады Академии наук, 1995, т. 340 (3), с. 400-403.

Рогожин Е.А., Имаев В.С., Смекалин О.П., Шварц Д. Тектоническая позиция и геологические проявления Могодского землетрясения 5 января 1967 г. в Центральной Монголии (взгляд сорок лет спустя) // Физика Земли, 2008, № 8, с. 70-82.

Тектоника Монгольской народной республики. Отв. ред. А.Л. Яншин. Москва, Издво Наука, 1974, 284 с.

Томуртогоо О. Тектоника и история развития Орхонской впадины (север Центральной Монголии) // Геотектоника, 1972, № 3, с, 61-74.

Bayasgalan A., Jackson J.A. A re-assessment of the faulting in the 1967 Mogod earthquakes in Mongolia // Geophys. J. Int. 1999. (138). P. 784-800.

Huang J., Chen W.P. Source mechanisms of the Mogod earthquake sequence of 1967 and the event of 1974 July 4 in Mongolia. // Geophys. J. R. astr. Soc., 1986. (84). P. 361-379.

Paleoseismology. Ed. McCalpin J., 2nd edition, Academic Press, 2009. 629 c.

Stuiver M., Reimer P.J., Reimer R.W. CALIB 7.1, 2018. (WWW program) at http://calib.org, accessed 2018-11-14. 
Tapponnier P., Molnar P. Active faulting and Cenozoic tectonics of the Tien Shan, Mongolia, and Baykal regions // Journal of Geophysical Research: Solid Earth, 1979, V. 84 (B7), 3425-3459.

Tectonic map of Mongolia. Scale of 1:1,000,000. Geological Information Center, MRAM 2002.

Tomurtogoo O. Tectonics of Mongolia. A Brief Explanatory Note to the Tectonic Map of Mongolia at a scale of 1:1,000,000. Geological Information Center, MRAM 2002. 42 p. 


\begin{abstract}
Подписи к рисункам к статье О.П. Смекалина и А.В. Чипизубова
"Активизация разломов Центральной Монголии в голоцене по результатам изучения дислокаций Могодского землетрясения".
\end{abstract}

Рис. 1. Одна из меридиональных трещин, образовавшихся при Могодском землетрясении на южном фланге Хулжингольского разлома (северо-восточный склон хребта Тулэт). Красной стрелкой обозначено место деформаций, показанных на рис. 2. Фото 2007 г.

Рис. 2. Фрагмент дислокации, показанной на рис. 1. Разрывы дернового слоя на склонах при отсутствии рыхлых осадков сохраняются в первозданном виде на протяжении многих десятилетий в климатических условиях монгольской степи. Фото 2007 г.

Рис. 3. Взбросовый уступ в зоне Тулэтского разлома. Вид на северо-запад. На переднем плане взбросовым уступом образована тектоническая дамба высотой 1.5-2.5 м, препятствующая сносу по склону в северо-восточном направлении. Фото 2007 г.

Рис. 4. Сейсмотектоническая схема эпицентральной области Могодского землетрясения и прилегающих территорий. 1 - активизированные разломы: Тулэтский (а) и Хулжингольский (b); 2 - региональный Баянгольский разлом (а) и прочие геологические разломы (b); 3 - неогеновые базальты; 4 - геолого-тектонические границы: мезозойского Орхонского прогиба (а) и горста, рассекающего его северную часть (b), среднепозднемезозойских образований (с). Схема составлена с использованием данных [Tectonic map of Mongolia, 2002]. Расположение эпицентров землетрясения 5.01.1967 г. и его афтершоков (и их магнитуды) нанесены согласно [Нацаг-Юм и др., 1971].

Рис. 5. Схема расположения эпицентров подсобытий землетрясения 5.1.1967 г. и афтершока 20.1.1967 г. и канав в зонах Хулжингольского и Тулэтского разломов. Номера фокальных механизмов: 1-3 - подсобытия главного землетрясения, 4 - афтершока 20.1.1967г. Условные обозначения: 1 - расположение эпицентров с номерами соответствующих фокальных механизмов (для третьего подсобытия определены два альтернативных решения по эпицентрам 3' и 3"); 2 - расположение и ориентация канав; 3 дислокации, Могодского землетрясения сохранившиеся до настоящего времени; 4 несохранившиеся дислокации Могодского землетрясения; 5 - Могодский разлом - югозападная граница Халзанского горста. Расположение эпицентров и фокальные механизмы приводятся по [Huang, Chen, 1986]. 
Рис. 6. Одна из вертикальных трещин в продольной северо-восточной стенке канавы 1. Трещиной на глубину 1.0-1.5 м разбит слой плотной окаменевшей супеси. Вверху трещина упирается в тальвег рва растяжения. Расстояние между соседними линиями сетки 1 метр. Ориентация канавы С-3 315 - Ю-В $135^{\circ}$.

Рис. 7. Трещина в торцовой северо-западной стенке канавы 1. 1 - границы бортов трещины (а) и погребенных почвенных слоев (b); 2 - места отбора проб на анализы ${ }^{14} \mathrm{C}$ c указанием лабораторного номера и радиоуглеродного возраста.

Рис. 8. Схема корреляции радиоуглеродных датировок. Верхняя граница возраста палеоземлетрясения (TuPEQ1) показана волнистой линией. Эта граница либо определяется временем формирования палеопочвы датированной пробой ЛУ-8807, или несколько моложе нее.

Рис. 9. Канава 2. В торцевой стенке видны зеленоватые трахеандезитовые порфириты позднетриасового возраста, раздробленные до состояния плотноупакованной дресвы.

Рис. 10. Разрез северо-западной стенки канавы 2. Условные обозначения: 1 коренные кристаллические породы, 2 - то же в сильно раздробленном виде, 3 - щебенка с песчано-дресвяным наполнителем, 4 - песок с дресвой, 5 - места отбора проб на радиоуглеродный анализ, 6 - осыпи коллювиального клина, возникшие после палеособытия (Tr2PEQ1). Вверху упрощенный уменьшенный разрез с основными кинематическими характеристиками: суммарной амплитудой смещения при двух последних землетрясениях (3.5 м) и видимой амплитудой смещения при более ранних землетрясениях (1.2 м). 
Табл. Радиоуглеродные и калиброванные значения возраста проб

\begin{tabular}{|c|c|c|c|c|}
\hline №№ & Канава & $\begin{array}{c}\text { Лабораторный } \\
\text { номер }\end{array}$ & $\begin{array}{c}\text { Радиоуглеродный } \\
\text { возраст }\end{array}$ & $\begin{array}{c}\text { Календарный } \\
\text { возраст }\end{array}$ \\
\hline 1 & 1 & ЛУ-8794 & $10800 \pm 320$ & cal BC 11379: cal BC 9765 \\
\hline 2 & 1 & ЛУ-8795 & $7690 \pm 170$ & cal BC 7034: cal BC 6235 \\
\hline 3 & 2 & ЛУ-8806 & $1260 \pm 110$ & cal AD 596: cal AD 996 \\
\hline 4 & 2 & ЛУ-8807 & $1180 \pm 80$ & cal AD 675: cal AD 994 \\
\hline
\end{tabular}

П р и м е ч а н и е : индексы в лабораторных номерах: ЛУ - научная лаборатория геоморфологических и палеогеографических исследований полярных регионов и Мирового океана СПбГУ, САМS - Center for Accelerator Mass Spectrometry, Lawrence Livermore National Laboratory P.O. Box 808, L-397, Livermore, California 94550, USA; калибровка радиоуглеродных образцов выполнена с помощью компьютерной программы CALIB [Stuiver et al., 2018]. 


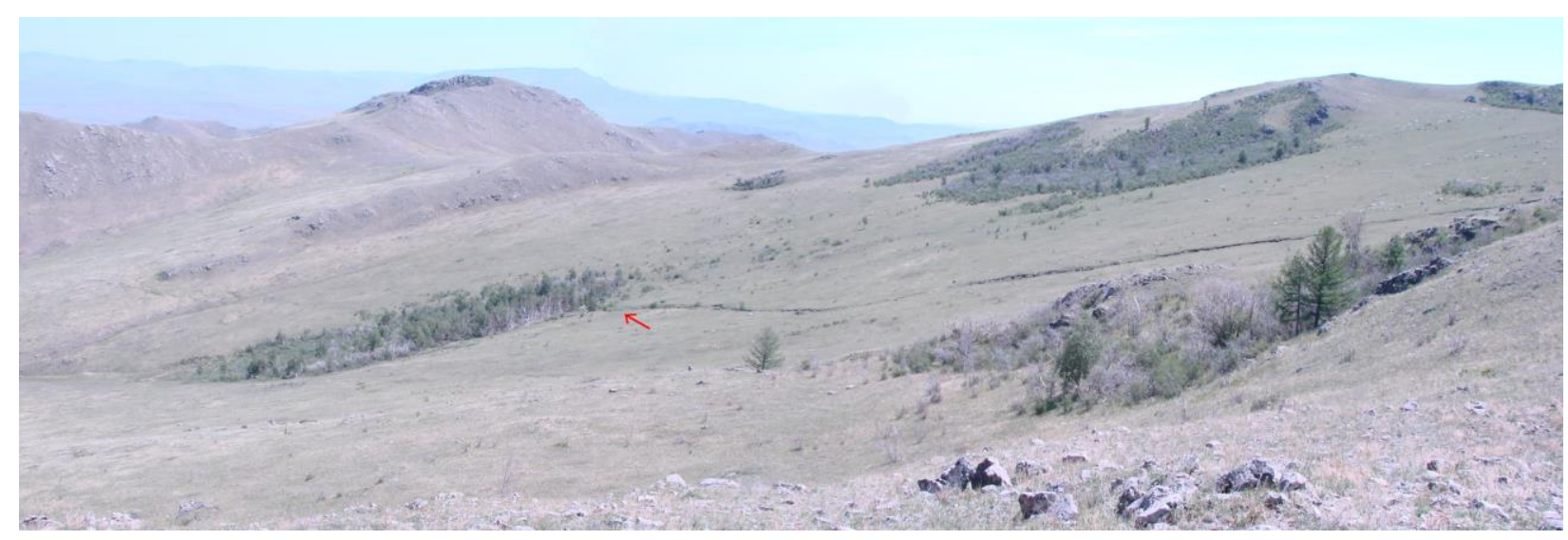

Рис. 1. Одна из меридиональных трещин, образовавшихся при Могодском землетрясении на южном фланге Хулжингольского разлома (северо-восточный склон хребта Тулэт). Красной стрелкой обозначено место деформаций, показанных на рис. 2. Фото 2007 г. 


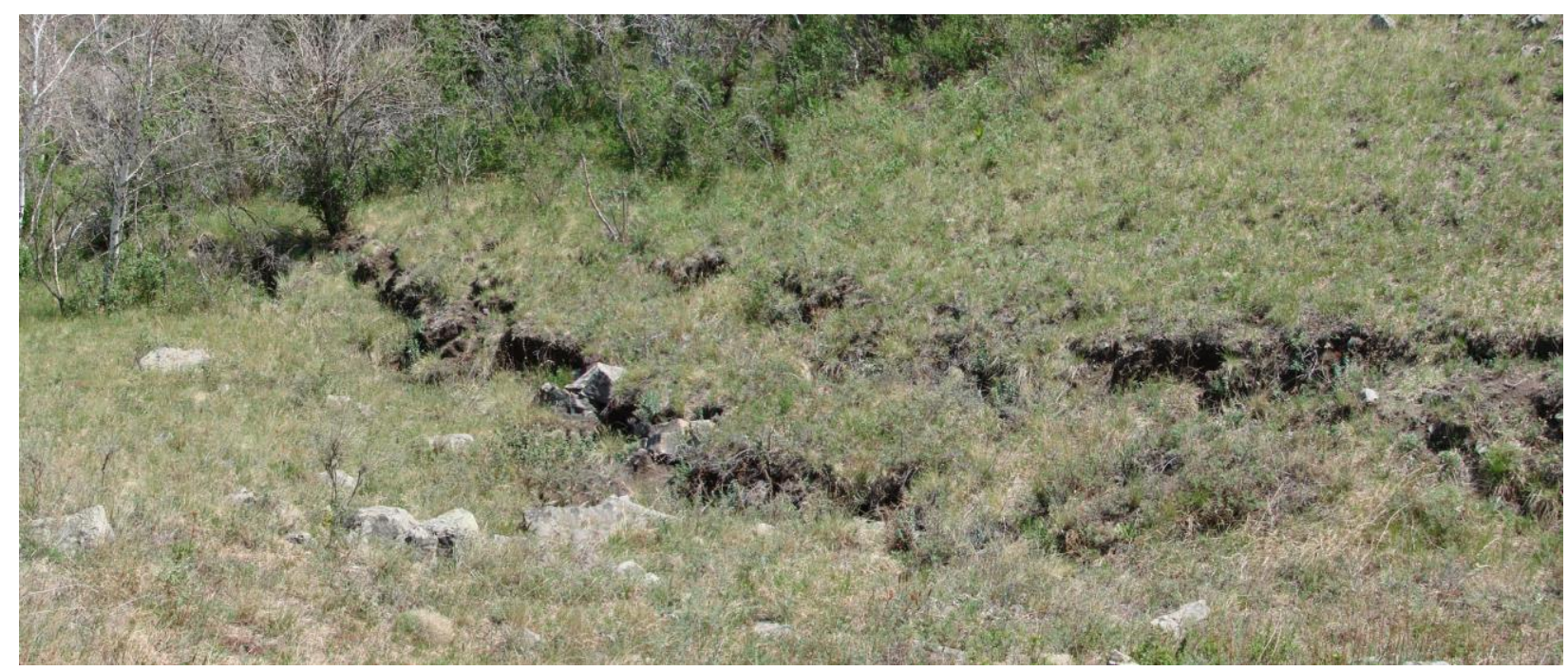

Рис. 2. Фрагмент дислокации, показанной на рис. 1. Разрывы дернового слоя на склонах при отсутствии рыхлых осадков сохраняются в первозданном виде на протяжении многих десятилетий в климатических условиях монгольской степи. Фото 2007 г. 


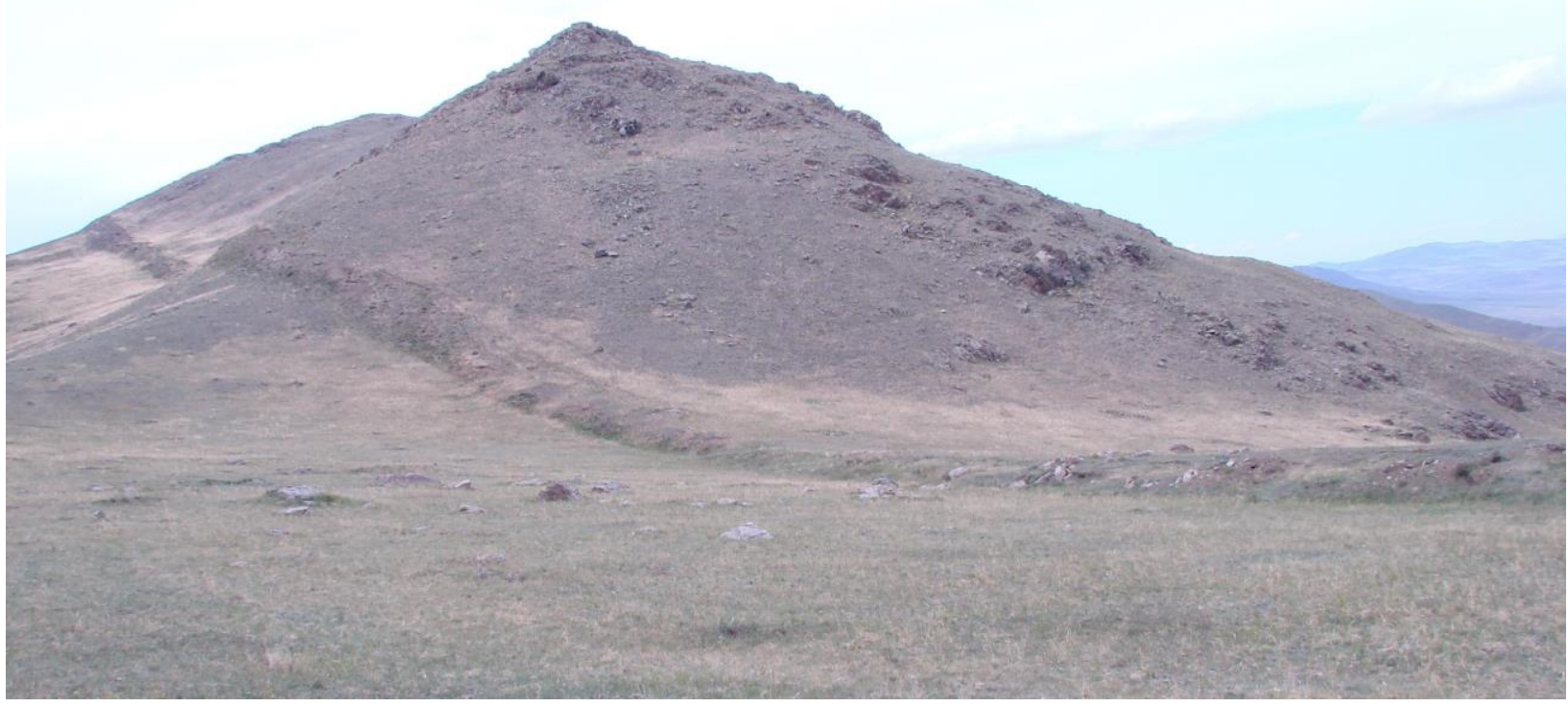

Рис. 3. Взбросовый уступ в зоне Тулэтского разлома. Вид на северо-запад. На переднем плане взбросовым уступом образована тектоническая дамба высотой 1.5-2.5 м, препятствующая сносу по склону в северо-восточном направлении. Фото 2007 г. 


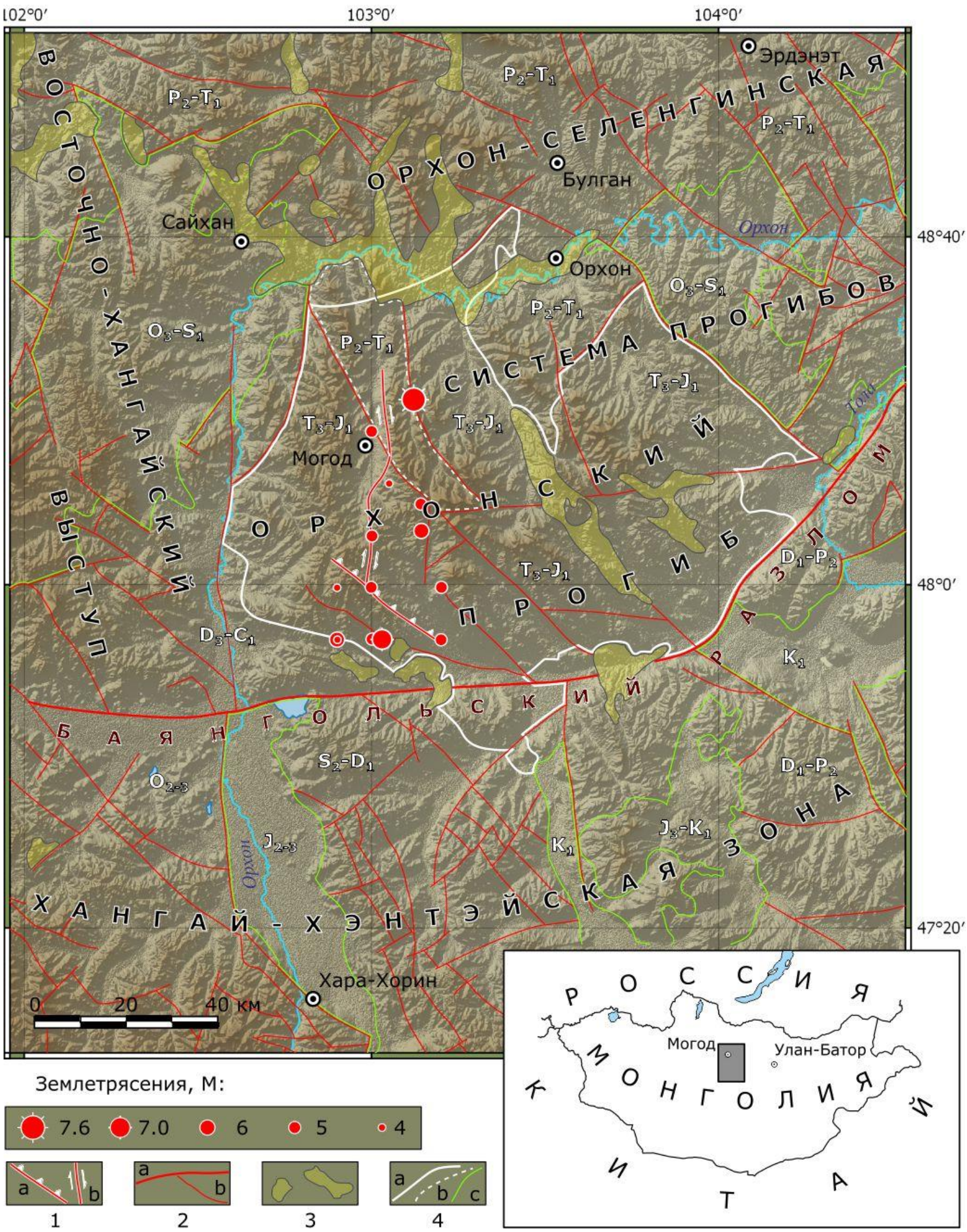

Рис. 4. Сейсмотектоническая схема эпицентральной области Могодского землетрясения и прилегающих территорий. 1 - активизированные разломы: Тулэтский (a) и Хулжингольский (b); 2 - региональный Баянгольский разлом (a) и прочие геологические разломы (b); 3 - неогеновые базальты; 4 - геолого-тектонические границы: мезозойского Орхонского прогиба (а) и горста, рассекающего его северную часть (b), среднепозднемезозойских образований (c). Схема составлена с использованием данных [Tectonic map of Mongolia, 2002]. Расположение эпицентров землетрясения 5.01.1967 г. и его афтершоков (и их магнитуды) нанесены согласно [Нацаг-Юм и др., 1971]. 


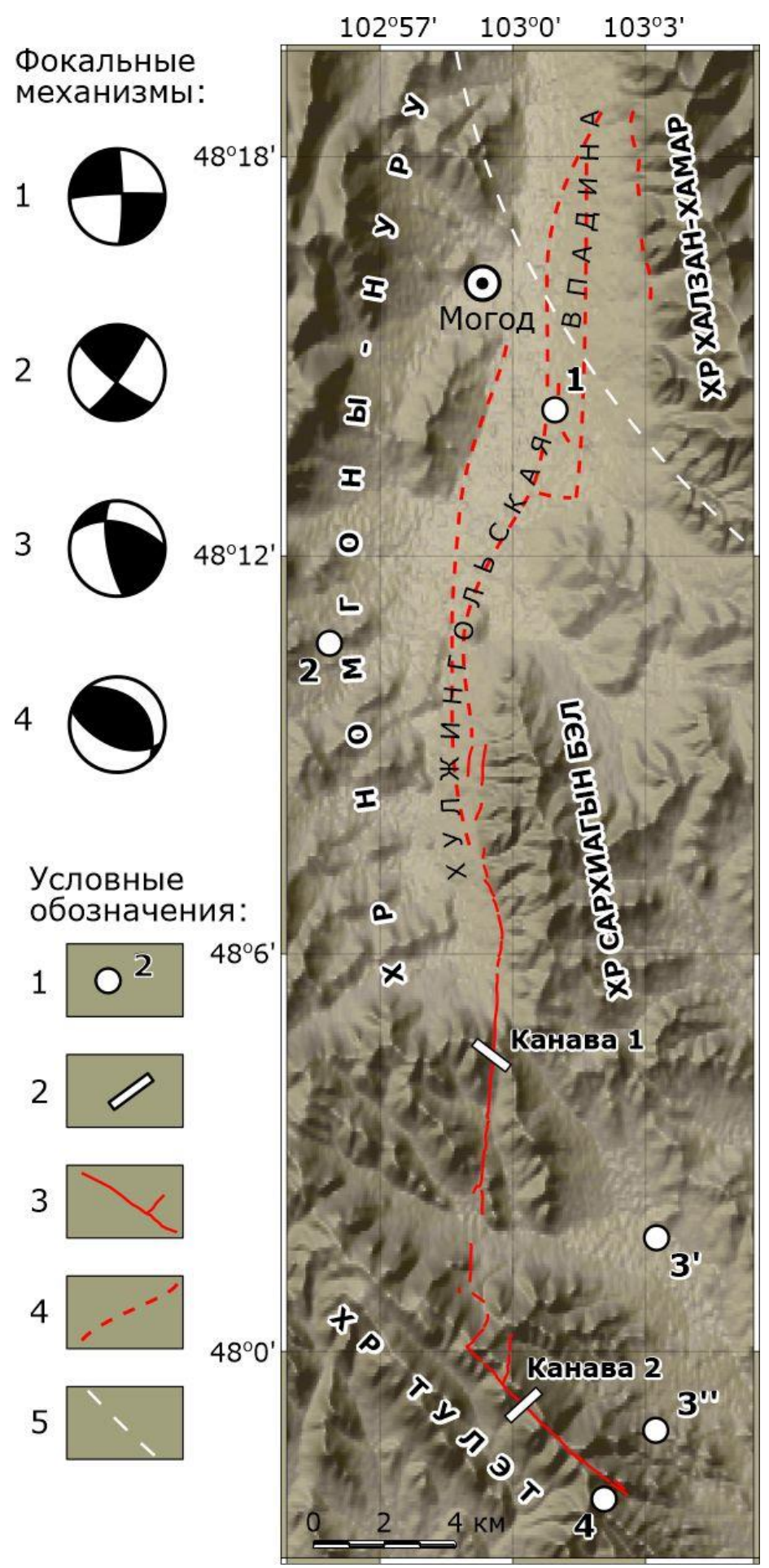

Рис. 5. Схема расположения эпицентров подсобытий землетрясения 5.1.1967 г. и афтершока 20.1.1967 г. и канав в зонах Хулжингольского и Тулэтского разломов. Номера фокальных механизмов: 1-3 - подсобытия главного землетрясения, 4 - афтершока 20.1.1967г. Условные обозначения: 1 - расположение эпицентров с номерами соответствующих фокальных механизмов (для третьего подсобытия определены два альтернативных решения по эпицентрам 3' и 3"); 2 - расположение и ориентация канав; 3 дислокации, Могодского землетрясения сохранившиеся до настоящего времени; 4 несохранившиеся дислокации Могодского землетрясения; 5 - Могодский разлом - югозападная граница Халзанского горста. Расположение эпицентров и фокальные механизмы приводятся по [Huang, Chen, 1986]. 


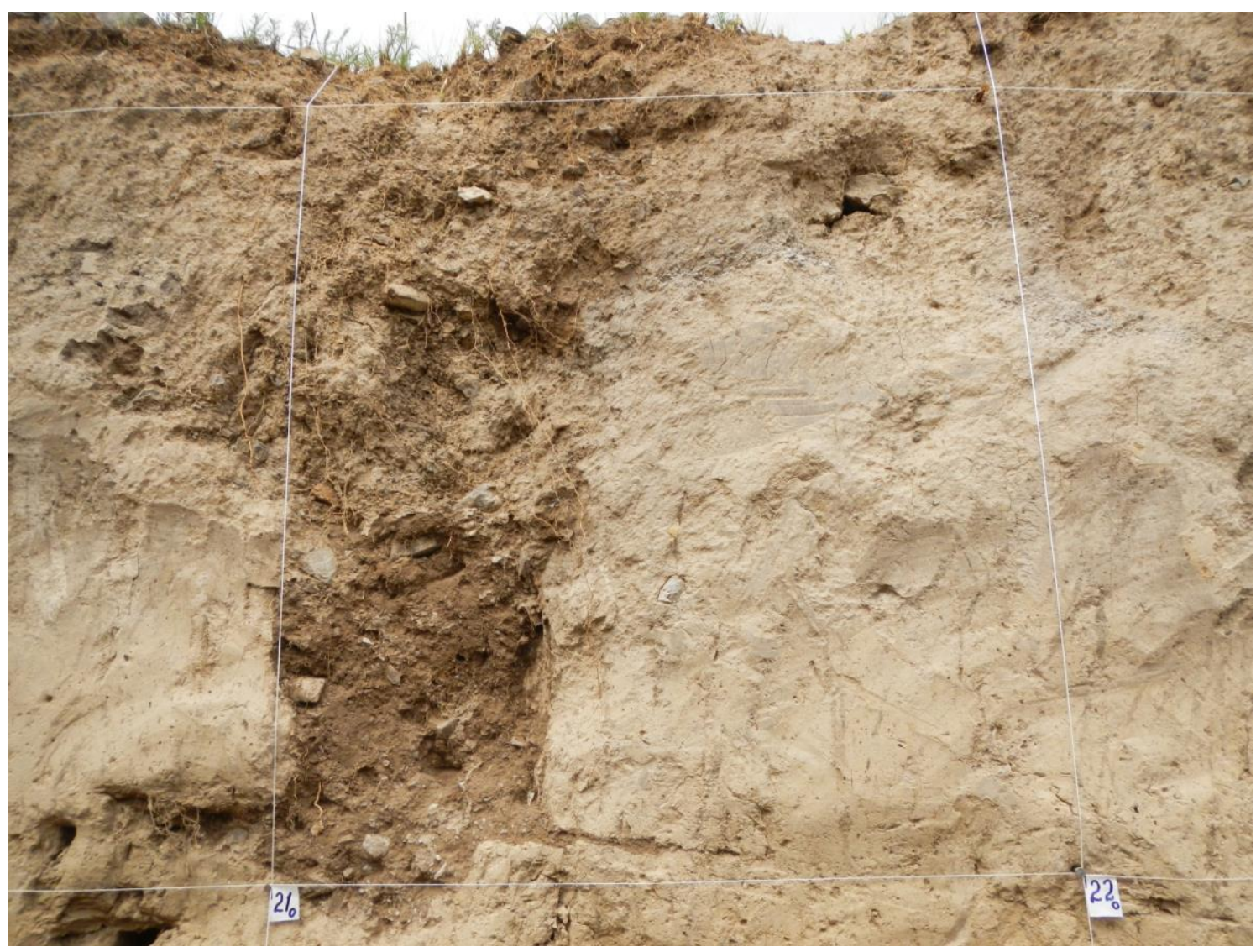

Рис. 6. Одна из вертикальных трещин в продольной северо-восточной стенке канавы 1. Трещиной на глубину 1.0-1.5 м разбит слой плотной окаменевшей супеси. Вверху трещина упирается в тальвег рва растяжения. Расстояние между соседними линиями сетки 1 метр. Ориентация канавы С-3 $315^{\circ}-$ Ю-В $135^{\circ}$. 


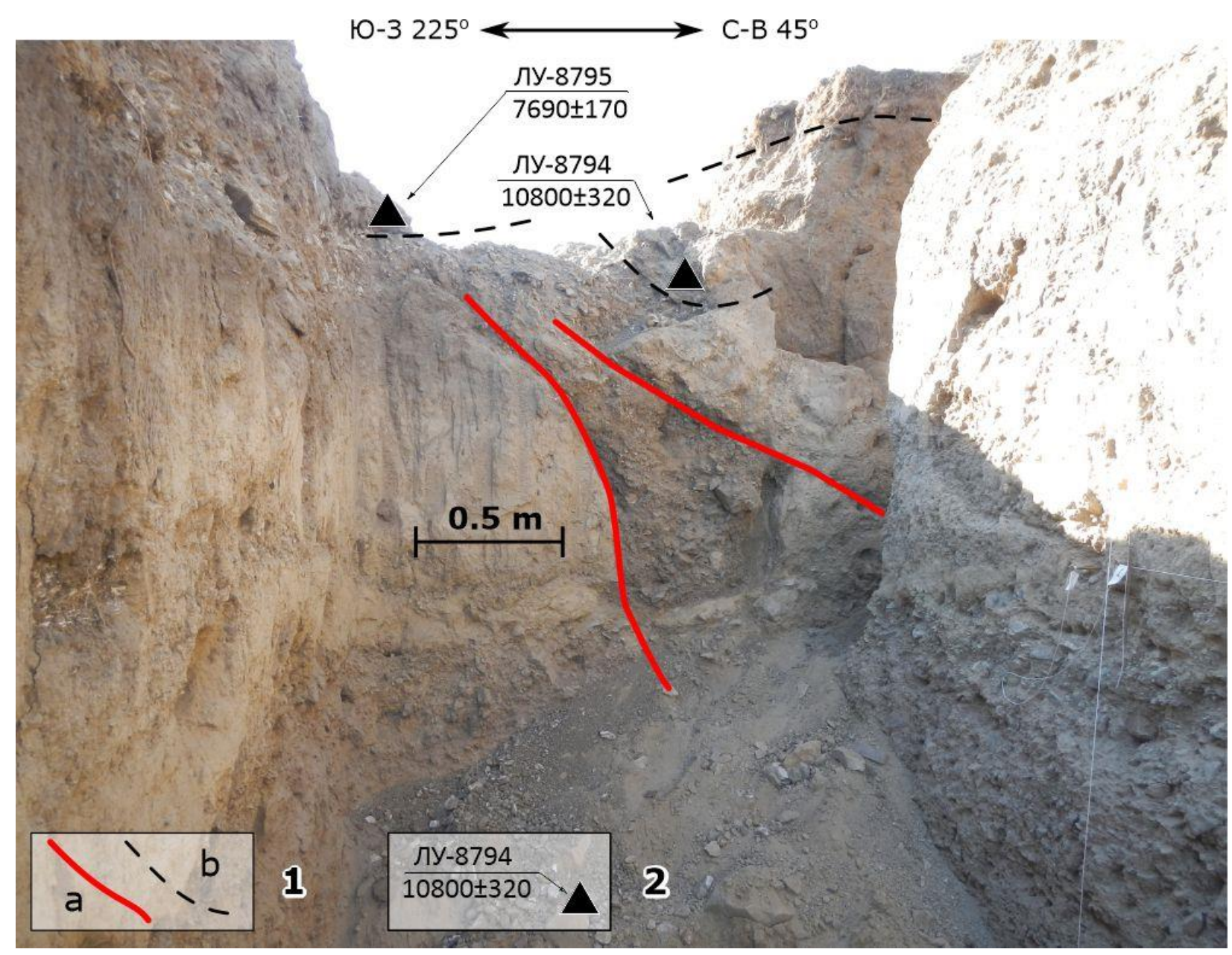

Рис. 7. Трещина в торцовой северо-западной стенке канавы 1. 1 - границы бортов трещины (a) и погребенных почвенных слоев (b); 2 - места отбора проб на анализы ${ }^{14} \mathrm{C}$ с указанием лабораторного номера и радиоуглеродного возраста. 


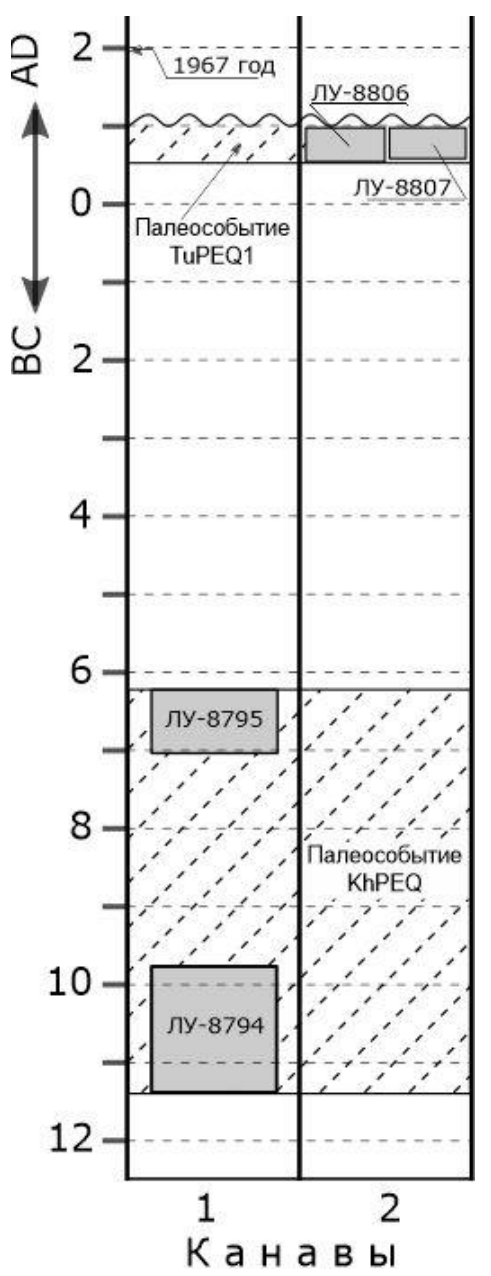

Рис. 8. Схема корреляции радиоуглеродных датировок. Верхняя граница возраста палеоземлетрясения (TuPEQ1) показана волнистой линией. Эта граница либо определяется временем формирования палеопочвы датированной пробой ЛУ-8807, или несколько моложе нее. 


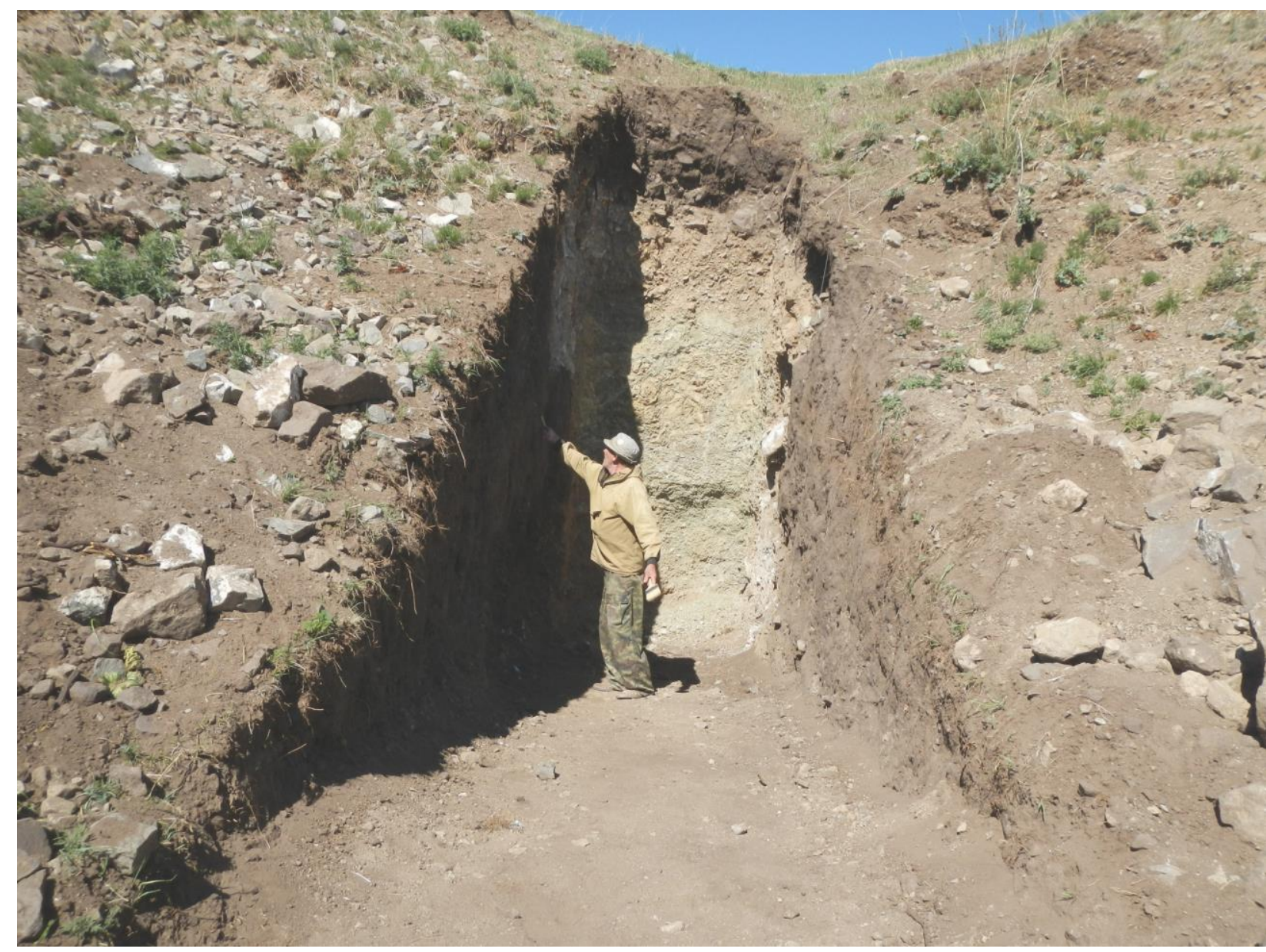

Рис. 9. Канава 2. В торцевой стенке видны зеленоватые трахеандезитовые порфириты позднетриасового возраста, раздробленные до состояния плотноупакованной дресвы. 


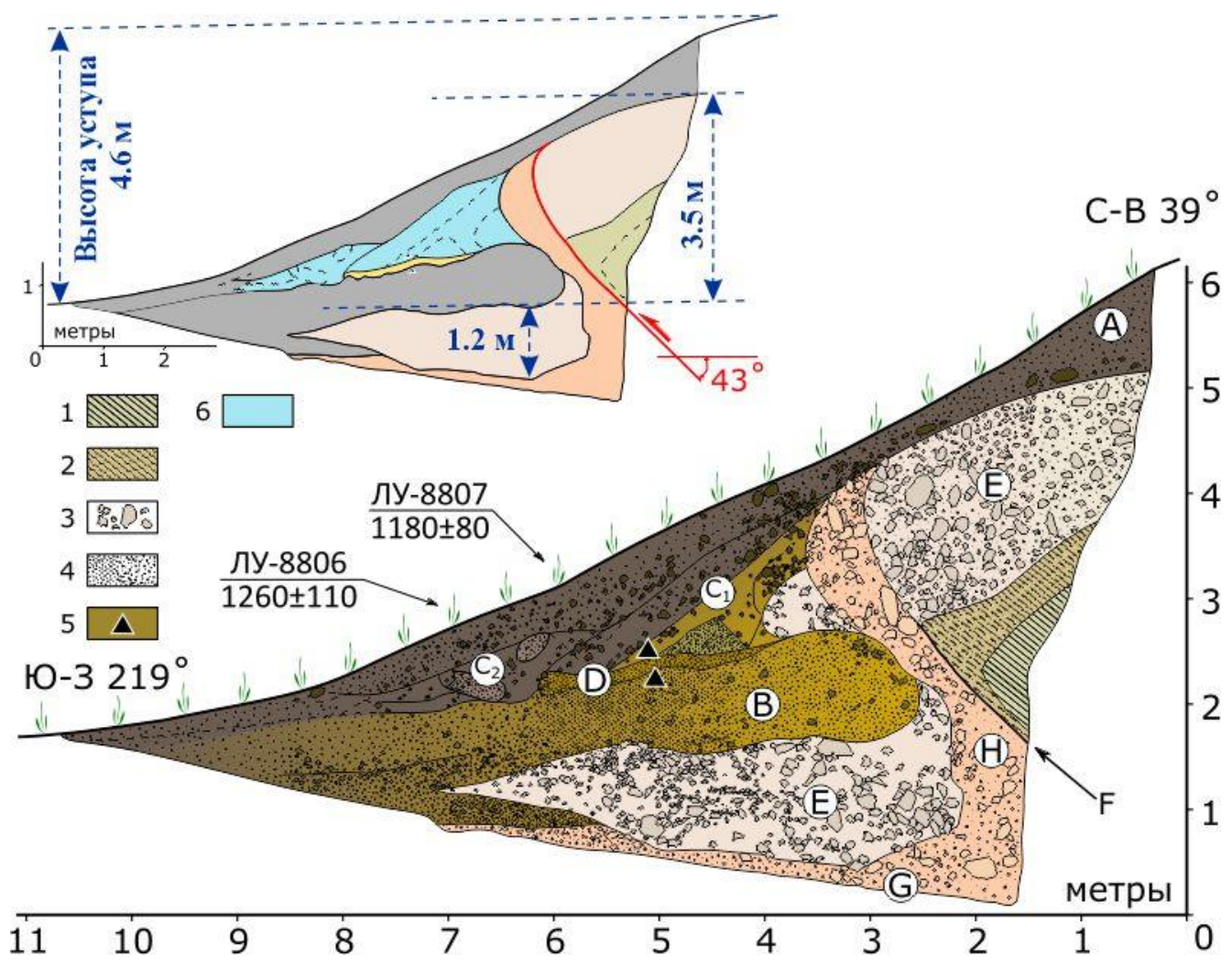

Рис. 10. Разрез северо-западной стенки канавы 2. Условные обозначения: 1 - коренные кристаллические породы, 2 - то же в сильно раздробленном виде, 3 - щебенка с песчанодресвяным наполнителем, 4 - песок с дресвой, 5 - места отбора проб на радиоуглеродный анализ, 6 - осыпи коллювиальных клиньев $\mathrm{C}_{1}$ и $\mathrm{C}_{2}$. Вверху упрощенный уменьшенный разрез с основными кинематическими характеристиками: суммарной амплитудой смещения при двух последних землетрясениях (3.5 м) и видимой амплитудой смещения при более ранних землетрясениях (1.2 м). 